\title{
SUATU PERBANDINGAN PENGATURAN CORPORATE SOCIAL RESPONSIBILITY (CSR) DI TAIWAN DAN DI INDONESIA
}

\author{
Sri Bakti Yunari \\ Fakultas Hukum Universitas Trisakti \\ Tomang, Grogol petamburan, Jakarta Barat \\ Email : sby.fhusakti@gmail.com / sbyunari.trisakti@yahoo.com
}

\begin{abstract}
Regulation comparison between Corporate Social and Environmental Responsibility (CSER) in Indonesia and Corporate Social Responsibility in Taiwan, aiming to compare the regulation of CSR in Taiwan and CSER in Indonesia. This Comparison carried out using the normative research method, which analyzed descriptively illustrating that regulation CSER at Art 74 Indonesian Law No. 40 of 2007 on Limited Company in conjuction with Government regulation Number 47 of 2012 on Social and Environmental Responsibility of limited company compared with Corporate Social Responsibility Regulation in Taiwan as required by the Taiwan Stock Exchange Corporation (TWSE) and GreTai Securities Market (GTSM)
\end{abstract}

Keywords: Corporation Law, Corporate Social Responsibility, Regulation, Indonesia and Taiwan

\begin{abstract}
Abstrak
Perbandingan Pengaturan Tanggung Jawab Sosial dan Lingkungan Perseroan (TJSLP) di Indonesia dan Pengaturan Corporate Social Responsibility (CSR) di Taiwan, bertujuan untuk mengambarkan perbandingan pengaturan CSR di Taiwan dan Pengaturan TJSLP di Indonesia. Perbandingan pengaturan tentang TJSLP di Indonesia dan Taiwan, dilakukan dengan mengunakan metode penelitian yuridis normatif, yang dianalisis secara deskriptif yang menggambarkan bahwa pengaturan TJSLP di Indonesia di dalam Pasal 74 UU No. 40 Tahun 2007 tentang Perseroan Terbatas juncto Peraturan Pemerintah No. 47 Tahun 2012 tentang Tanggung Jawab Sosial dan Lingkungan Perseroan Terbatas (PP-TJSLP) diperbandingkan dengan pengaturan Corporate Sosial Responsibility di Taiwan sebagaimana diatur oleh The Taiwan Stock Exchange Corporation ("TWSE") and GreTai Securities Market ("GTSM") mempunyai persamaan dan perbedaan.
\end{abstract}

\section{Kata Kunci: Hukum Korporasi, Corporate Social Responsibility, Pengaturan, Indonesia dan Taiwan.}

\section{A. Pendahuluan}

Berlakunya Undang-undang No. 40 Tahun 2007 tentang Perseroan Terbatas (selanjutnya disebut UUPT) pada tanggal 16 Agustus 2007 (Lembaran Negara Republik Indonesia Tahun 2007 Nomor 106 - Tambahan Lembaran Negara Republik Indonesia Nomor 4756), telah mengakomodasi berbagai ketentuan mengenai Perseroan, baik berupa penambahan ketentuan baru, perbaikan penyempurnaan, maupun mempertahankan ketentuan lama yang dinilai masih relevan. Untuk lebih memperjelas hakikat Perseroan, di dalam UUPT ini ditegaskan bahwa 
Perseroan adalah badan hukum yang merupakan persekutuan modal, didirikan berdasarkan perjanjian, melakukan kegiatan usaha dengan modal dasar yang seluruhnya terbagi dalam saham, dan memenuhi persyaratan yang ditetapkan dalam Undang-Undang ini serta peraturan pelaksanaannya.

Salah satu hal baru yang diatur oleh UUPT diantaranya adalah mengenai diaturnya Tanggung Jawab Sosial dan Lingkungan Perseroan (TJSLP), sebagaimana diatur dalam Pasal 74 UUPT, yang berbunyi sbb: ${ }^{1}$

(1) Perseroan yang menjalankan kegiatan usahanya dibidang dan/atau berkaitan dengan sumber daya alam, wajib melaksanakan tanggung jawab sosisal dan lingkungan;

(2) Tanggung jawab sosial dan lingkungan sebagaimana dimaksud pada ayat (1) merupakan kewajiban perseroan yang dianggarkan dan diperhitungkan sebagai biaya perseroan yang pelaksanaannya dilakukan dengan memperhatikan kepatutan dan kewajaran;

(3) Perseroan yang tidak melaksanakan kewajiban sebagaimana dimaksud pada ayat (1) dikenai sanksi sesuai dengan ketentuan perundang-undangan;

(4) Ketentuan lebih lanjut mengenai tanggung jawab sosial dan lingkungan diatur dengan Peraturan Pemerintah.

Ketentuan mengenai TJSLP tersebut diatas, bertujuan mewujudkan pembangunan ekonomi berkelanjutan guna meningkatkan kualitas kehidupan dan lingkungan yang bermanfaat bagi Perseroan itu sendiri, komunitas setempat dan masyarakat pada umumnya. Ketentuan ini juga dimaksudkan untuk mendukung terjalinnya hubungan Perseroan yang serasi, seimbang dan sesuai dengan lingkungan, nilai, norma, dan budaya masyarakat setempat, maka ditentukan bahwa Perseroan yang kegiatan usahanya di bidang dan/atau berkaitan dengan sumber daya alam wajib melaksanakan TJSLP. Untuk melaksanakan kewajiban Perseroan tersebut, kegiatan TJSLP harus dianggarkan dan diperhitungkan sebagai biaya Perseroan yang dilaksanakan dengan memperhatikan kepatutan dan kewajaran. Kegiatan tersebut dimuat dalam laporan tahunan Perseroan. Jika perseroan tidak melaksanakan TJSLP, maka Perseroan yang bersangkutan dikenai sanksi sesuai dengan ketentuan peraturan perundang-undangan.

Fenomena CSR sebagai kewajiban moral tersebut memang menjadi pro dan kontra manakala di Indonesia, dengan diaturnya TJSLP di dalam Pasal 74 UUPT, maka kewajiban moral yang selama ini melekat pada CSR, berubah menjadi kewajiban hukum (legal obligation), dan sifat CSR yang voluntary dianut oleh negara-negara selama ini, di Indonesia berubah menjadi bersifat Mandatory.

Dimasukkannya konsep TJSLP dalam UUPT yang baru di Indonesia, sebenarnya telah menunjukkan betapa pentingnya CSR tersebut bagi kelangsungan dunia usaha, khususnya bagi perseroan yang bidang usahanya berkaitan dengan sumber daya alam. Atas dasar

Udang-undang No. 40 Tahun 2007 tentang Perseroan Terbatas (Lembaran Negara Republik Indonesia Tahun 2007 Nomor 106 - Tambahan Lembaran Negara Republik Indonesia Nomor 4756), Pasal 74. 
pengaturan CSR dalam UUPT tersebut, maka seharusnya setiap perseroan di Indonesia menerapkan CSR, karena jika tidak akan dikenakan sanksi. Akan tetapi mengenai pengaturan sanksi terhadap pelanggaran tidak diterapkannya CSR, tidak tegas diatur didalam UUPT, karena sanksi dan hal-hal lain tentang CSR ketentuannya akan diatur lebih lanjut dalam Peraturan Pemerintah sebagaimana disebutkan dalam Pasal 74 ayat (4) UUPT. ${ }^{2}$

Sebagai tindak lanjut Pasal 74 ayat (4) UUPT tersebut, pada tanggal 4 April 2012, pemerintah telah mengeluarkan Peraturan Pemerintah No. 47 Tahun 2012 tentang Tanggung Jawab Sosial dan Lingkungan Perseroan Terbatas, selanjunta disebut PP-TJSLP (Lembaran Negara Republik Indonesia Tahun 2012 Nomor 89 - Tambahan Lembaran Negara Republik Indonesia Nomor 5305), dengan maksud untuk: ${ }^{3}$

1. meningkatkan kesadaran Perseroan terhadap pelaksanaan tanggung jawab sosial dan lingkungan di Indonesia;

2. memenuhi perkembangan kebutuhan hukum dalam masyarakat mengenai tanggung jawab sosial dan lingkungan; dan

3. menguatkan pengaturan tanggung jawab sosial dan lingkungan yang telah diatur dalam berbagai peraturan perundang-undangan sesuai dengan bidang kegiatan usaha Perseoan yang bersangkutan.

Keberadaan PP - TJSLP sebagai peraturan pelaksanaan tersebut, menurut penulis hanya merupakan penegasan kembali apa yang diatur didalam Pasal 74 UUPT, sehingga secara materi tidak merubah kondisi pengaturan TJSLP seperti sebelum dan sesudah berlakunya PP - TJSLP. Dimana TJSLP diberlakukan hanya terhadap Perseroan yang menjalankan kegiatan usahanya di bidang dan/atau berkaitan dengan sumber daya alam, yang dilakukan di dalam ataupun di luar lingkungan Perseroan berdasarkan rencana kerja tahunan yang memuat rencana kegiatan dan anggaran yang dibutuhkan untuk pelaksanaannya dengan memperhatikan kepatutan dan kewajaran dan wajib dimuat dalam laporan tahunan Perseroan untuk dipertanggungjawabkan kepada RUPS. Demikian pula mengenai sanksi yang diatur di dalam PP-TJSLP tersebut sifatnya hanya merupakan penegasan kembali pengaturan pengenaan sanksi sebelumnya yang merujuk pada pengenaan sanksi di dalam UU Sektoral yang terkait, dalam hal ini terdapat 17 UU Sektoral yang dimaksud. Dimana dari 17 UU Sektoral yang dimaksud ternyata hanya 12 UU Sektoral yang mengatur tentang sanksi jika tidak melaksanakan TJSLP, sisanya di 5 UU Sektoral tidak mengatur sehingga pengaturan sanksi tersebut masih berpotensi menimbulkan ketidakpastian hukum didalam pelaksanaannya. Meskipun bagi Perseroan yang telah berperan dan melaksanakan TJSLP dapat diberikan penghargaan oleh instansi yang berwenang. Dalam hal ini tidak ada kejelasan mengenai instansi yang berwenang untuk memberikan penghargaan tersebut, sehingga keberadaan pasal tentang penghargaan di PP-TJSLP terkesan hanya sebuah retorika karena yang tidak didukung oleh pengaturan yang jelas.

Lihat bunyi Pasal 74 ayat (4) UUPT, yang menyatakan: "Ketentuan lebih lanjut mengenai Tanggung Jawab Sosial dan Lingkungan diatur dengan Peraturan Pemerintah.

3 Lihat bunyi penjelasan umum PP No. 47 Tahun 2012 tentang Tanggung Jawab Sosial dan Lingkungan Perseroan Terbatas. 
Berdasarkan pemaparan tersebut, maka banyak kalangan menilai bahwa regulasi TJSLP sebagai legal obligation di Indonesia masih mempunyai banyak kelemahan disamping kelebihan. Bagi yang pro berpendapat bahwa negara Indonesia termasuk sebagai salah satu negara yang telah cukup peduli terhadap CSR, bahkan pemerintah telah menjadikan CSR sebagai kewajiban hukum bagi perseroan sejak Tahun 2007, dengan memasukkan ketentuan CSR dalam Pasal 74 UU No. 40 Tahun 2007 tentang Perseroan Tersebut tersebut diatas. Sedangkan bagi yang kontra mengganggap kewajiban hukum dalam UUPT tersebut terlalu berlebihan dan tidak sesuai dengan filosofi awal diberlakukannya CSR bagi perseroan. Tentunya untuk mendudukkan posisi CSR itu sendiri sebagai kewajiban moral atau kewajiban hukum, maka peneliti merasa perlu melanjutkan penelitian tentang CSR ini dengan membandingkan pengaturan CSR di Negara lainnya, khususnya negara Taiwan. Dimana negara Taiwan telah mempunyai Corporate Social Responsibility Best Practice Principles for TWSE/GTSM Listed Companies yang juga mengacu pada G4-GRI (Global Reporting Inisiative), yang diberlakukan sejak tanggal 6 Februari 2010 dan di amandemen pada tanggal 7 November 2015. Serta Taiwan Stock Exchange Corporate Social Responsibility Governing The Preparation and Filing of Corporate Social Responsibility reports by TWSE list companies, yang diberlakukan tanggal 26 November 2014, yang kemudian diamandemen pada tanggal 27 Maret 2015. Dimana negara Taiwan telah mengeluarkan suatu kewajiban hukum (mandatory) berupa pembuatan laporan pelaksanaan CSR tersebut. Berdasarkan hal tersebut, maka penulis tertarik untuk melakukan kajian tentang pengaturan CSR tersebut di negara Taiwan. Oleh karena Taiwan saat ini dianggap sebagai negara pertama yang memberlakukan kewajiban pelaporan CSR bagi perusahaan yang terdaftar dalam TWSE di Asia Pasific. Sehingga diharapkan degan adanya kajian ini maka dapat digambarkan secara jelas mengenai pengaturan TJSLP di Indonesia dan pengaturan CSR di Taiwan sekaligus persamaan dan perbedaannya pengaturannya.

\section{B. Rumusan Permasalahan}

Berdasarkan pada Latar Belakang sebagaimana telah dijabarkan di atas, maka rumusan permasalahan dari penelitian ini adalah bagaimana Perbandingan Pengaturan TJSLP Di Indonesia Dan CSR Di Taiwan?

\section{Metode Penelitian}

Adapun tipe penelitian yang dipergunakan dalam penelitian ini adalah penelitian yuridis normatif, yaitu melakukan penelitian terhadap peraturan yang mengatur mengenai CSR baik di Indonesia maupun di Taiwan, khususnya ketentuan yang berbentuk peraturan perundangundangan dalam Hukum Korporasi di Indonesia dan Taiwan. Dimana penelitian ini bersifat deskriptif analitis, yaitu menggambarkan Konsep-Konsep CSR yang berlaku di dalam sistim hukum positif di Indonesia dan di Taiwan. Hal ini dilakukan berdasarkan persepsi bahwa setiap penelitian hukum selalu bertujuan untuk dapat memperoleh suatu ide-ide baru berupa konsep, doktrin maupun bahan hukum yang dapat diterapkan dalam pelaksanaan maupun 
penegakan hukum. ${ }^{4}$ Sumber data yang dipergunakan adalah data sekunder, dengan analisis yang dilakukan secara deskriptif melalui proses sistematisasi data dengan cara menyusun keseluruhan data yang telah diperoleh dan dikumpulkan, untuk selanjutnya dilakukan deskriptif dalam bentuk uraian tertulis ${ }^{5}$.

\section{Pembahasan}

\section{Pengaturan Tanggung Jawab Sosial Dan Lingkungan Perseroan (TJSLP) Di Indonesia.}

Pengaturan tentang Corporate Sosial dan Responsibility (CSR) di Indonesia, yang dikenal dengan istilah Tanggung Jawab Sosial dan Lingkungan Perseroan (TJSLP), selain diatur di dalam Pasal 74 UU No. 40 Tahun 2007 tentang Perseroan Terbatas (UUPT), tetapi juga diatur di dalam Undang-undang No. 25 Tahun 2007 tentang Penanaman Modal (UUPM) dengan istilah Tanggung Jawab Sosial Perusahaan (TJSP). Untuk istilah TJSP dirumuskan di dalam Pasal 15 huruf (b) UUPM. Menurut penjelasan Pasal 15 huruf (b) UUPM tersebut, menyatakan bahwa: "setiap penanam modal wajib melaksanakan tanggung jawab sosial perusahaan yaitu tanggung jawab yang melekat pada setiap perusahaan penanaman modal untuk tetap menciptakan hubungan yang serasi, seimbang, dan sesuai dengan lingkungan, nilai, norma, dan budaya masyarakat setempat". Secara yuridis formal menurut UUPM, semua perusahaan yang merupakan perusahaan penanaman modal (Penanaman Modal Dalam Negeri dan Penanaman Modal Asing) wajib hukumnya untuk melaksanakan Tanggung Jawab Sosial Perusahaan atau Corporate Social Responsibility, baik untuk perusahaan yang berbentuk Perseroan Terbatas, Persekutuan Firma, Persekutuan Komanditer maupun Perusahaan Perseorangan. ${ }^{6}$

Selanjutnya untuk pengaturan tentang Tanggung Jawab Sosial dan Lingkungan Perseroan (TJSLP) di dalam Undang-undang No. 40 Tahun 2007 tentang Perseroan Terbatas (UUPT), terdapat pada BAB V tentang Tanggung Jawab Sosial dan Lingkungan, khususnya Pasal 74 UUPT tentang TJSLP. Sedangkan istilah dan defenisi Tanggung Jawab Sosial dan Lingkungan (TJSLP) di dalam UUPT terdapat di dalam Bab I Ketentuan Umum, khususnya Pasal 1 angka (3), yang menyatakan bahwa TJSLP adalah: "Komitmen perseroan untuk berperan serta dalam pembangunan ekonomi berkelanjutan guna meningkatkan kualitas kehidupan dan lingkungan yang bermanfaat, baik bagi perseroan sendiri, komunitas setempat, maupun masyarakat pada umumnya". Lebih lanjut di dalam Bab V - Pasal 74 UUPT, menyatakan bahwa :

(1) Perseroan yang menjalankan kegiatan usahanya di bidang dan/atau berkaitan dengan sumber daya alam wajib melaksanakan Tanggung Jawab Sosial dan Lingkungan.

\footnotetext{
Soerjono Soekanto, Pengantar Penelitian Hukum, Penerbit UI Press, Jakarta, 1982, hlm. 28.

Lexy J. Moleong, Metodologi Penelitian Kualitatif Remadja Karya, Bandung, 1989, hlm. 112.

Kursif penulis, berdasarkan interpretasi Pasal 5 ayat (1) dan (2) UUPM.
} 
(2) Tanggung Jawab Sosial dan Lingkungan sebagaimana dimaksud pada ayat (1) merupakan kewajiban Perseroan yang dianggarkan dan diperhitungkan sebagai biaya Perseroan yang pelaksanaannya dilakukan dengan memperhatikan kepatutan dan kewajaran.

(3) Perseroan yang tidak melaksanakan kewajiban sebagaimana dimaksud pada ayat (1) dikenai sanksi sesuai dengan ketentuan peraturan perundang-undangan.

(4) Ketentuan lebih lanjut mengenai Tanggung Jawab Sosial dan Lingkungan diatur dengan Peraturan Pemerintah.

Berdasarkan defenisi pada pasal-pasal tersebut, maka istilah dan pengertian TJSLP yang diatur dalam UUPT, mengandung makna yang inkonsistensi, bahkan di dalam prakteknya banyak menimbulkan pro dan kontra, karena bagi sebagian kalangan pengusaha keberadaan pengaturan TJSLP di dalam UUPT, khususnya pada Pasal 74 UUPT tersebut dirasa merugikan dalam penerapannya. Sehingga pada Tahun 2008, Kamar Dagang dan Industri (KADIN), Badan Pengurus Pusat Himpunan Pengusaha Indonesia (BPP-HIPMI), Ikatan Wanita Pengusaha Indonesia (IWAPI), PT. Lili Panma, PT. Apac Centra Centertex Tbk, dan PT. Kreasi Tiga Pilar, secara bersama-sama melakukan gugatan class action untuk menguji secara formil keberadaan materi Pasal 74 UUPT tersebut, terhadap UUD 1945 ke Mahkamah Konstitusi. Akan tetapi Mahkamah Konstitusi, dalam putusannya yang dijatuhkan pada tanggal 15 April 2009 dengan Putusan Nomor 53/PUU-VI/2008, menyatakan menolak gugatan class action tersebut, dengan alasan secara formil ketentuan Bab V Pasal 74 UUPT tidak bertentangan dengan UUD 1945. Hal tersebut didasarkan kepada pertimbangan, bahwa istilah TJSLP yang dipergunakan di dalam UUPT, tidak identik dengan istilah CSR yang selama ini dikenal di dalam dunia bisnis.

Berdasarkan analisis dari segi ilmu perundang-undangan, pada dasarnya definisi TJSLP sebagaimana dirumuskan dalam ketentuan umum Pasal 1 angka (3) UUPT, merupakan pengertian umum (begripsbepalingen) ${ }^{7}$, yang menjadi acuan bagi pengaturan dalam pasalpasal peraturan perundang-undangan selanjutnya. Sehingga ketentuan yang telah dirumuskan dalam ketentuan umum, tidak boleh diberikan pengertian yang berbeda dalam pasal-pasal selanjutnya. Adanya rumusan tentang "pengertian" yang berbeda antara bunyi Pasal 1 angka (3) dengan bunyi Pasal 74 ayat (1), (2) dan (3) serta penjelasannya, merupakan suatu perumusan yang inkonsistensi, tidak sinkron (contradictio in terminis) ${ }^{8}$, tumpang tindih dan ketidakjelasan aturan sehingga dapat menimbulkan ketidakpastian hukum dan dianggap bertentangan dengan prinsip efisiensi berkeadilan ${ }^{9}$. Oleh karena itu, dapat dikatakan secara materiil isi dari ketentuan TJSLP di dalam UUPT, dapat bertentangan pula dengan grundnorm

\footnotetext{
Maria Farida Indrati S, Ilmu Perundang-undangan - Proses dan Teknik Pembentukannya, Kanisius, Yogykarta, 2008, hal. 98.

8 Lihat bunyi Putusan Mahkamah Konstitusi Nomor 53/PUU-VI/2008 Perihal Pengujian Undang-undang Nomor 40 Tahun 2007 tentang Perseroan Terbatas, yang diputus pada tanggal 15 April 2009

9 Lihat Pasal 33 Ayat (4) UUD 1945, yang berbunyi, sbb: "Perekonomian nasional diselenggarakan berdasar atas demokrasi ekonomi dengan prinsip kebersamaan, efisiensi berkeadilan, berkelanjutan, berwawasan lingkungan, kemandirian serta dengan menjaga keseimbangan kemajuan dan kesatuan ekonomi nasional".
} 
(UUD 1945) yang berlaku di Indonesia, khususnya Pasal 28D ayat (1) ${ }^{10}$ dan Pasal 28I Ayat (2) ${ }^{11}$ UUD 1945.

Selanjutnya dikatakan didalam Penjelasan Pasal 74 UUPT, bahwa Ketentuan mengenai TJSLP di dalam UUPT tersebut bertujuan untuk tetap menciptakan hubungan Perseroan yang serasi, seimbang, dan sesuai dengan lingkungan, nilai, norma, dan budaya masyarakat setempat. Adapun yang dimaksud dengan "Perseroan yang menjalankan kegiatan usahanya di bidang sumber daya alam" adalah perseroan yang kegiatan usahanya mengelola dan memanfaatkan sumber daya alam. Sedangkan yang dimaksud dengan "Perseroan yang menjalankan kegiatan usahanya yang berkaitan dengan sumber daya alam" adalah Perseroan yang tidak mengelola dan tidak memanfaatkan sumber daya alam, tetapi kegiatan usahanya berdampak pada fungsi kemampuan sumber daya alam. Artinya jika sebuah perseroan (perusahaan yang berbentuk PT), yang kegiatan usahanya mengelola dan memanfaatkan sumber daya alam atau tidak mengelola dan tidak memanfaatkan sumber daya alam, tetapi berdampak pada fungsi kemampuan sumber daya alam, maka diharuskan melaksanakan kewajiban TJSLP, dengan akibat hukum jika perseroan tidak menjalankan kewajiban TJSLP tersebut, maka perseroan dapat dikenai sanksi sesuai dengan segala bentuk sanksi yang diatur dalam peraturan perundang-undangan yang terkait (UU Sektoral).

Jadi meskipun telah dibuat peraturan pelaksanaan dari Pasal 74 tersebut dalam PP No. 47 Tahun 2012 tentang Tanggung Jawab Sosial dan Lingkungan Perseroan Terbatas (selanjutnya disebut "PP-TJSLP"), akan tetapi ketentuan sanksi di dalam Pasal 7 PP-TJSLP tersebut juga tidak secara tegas mengatur, karena hanya menegaskan kembali pengaturan sanksi dari Pasal 74 ayat (3) UUPT, yang masih tetap merujuk pada UU sektoral terkait, maka secara yuridis formil bagi perseroan yang tidak melaksanakan TJSLP dapat diberlakukan ketentuan sanksi sebagaimana diatur di dalam peraturan perundang-undangan yang secara khusus mengatur dan terkait dengan pengelolaan, pemanfaatan, dan berdampak pada fungsi sumber daya alam.

Jika kita melihat lebih jauh sanksi yang dimaksud tersebut diatas, maka memang terdapat beberapa sanksi yang dapat diterapkan sebagaimana diatur di dalam peraturan perundangundangan khusus yang terkait (UU Sektoral). Berdasarkan hasil penelitian, ketentuan yang mengatur tentang sanksi terhadap pelanggaran kewajiban TJSLP yang diatur di dalam UU Sektoral sebagaimana dimaksud penjelasan Pasal 74 ayat (3) UUPT juncto Pasal 7 PP-TJSL, dimana hanya terdapat 12 (dua belas) UU Sektoral dari 17 (tujuh belas) UU Sektoral yang mengatur tentang kewajiban TJSLP sebagaimana dimaksud PP-TJSLP. Adapun ke 17 (tujuh belas) UU Sektoral yang mengatur tentang kewajiban TJSLP sebelum dan sesudah berlakunya UUPT, adalah: ${ }^{12}$

a. Undang-undang No. 5 Tahun 1984 tentang Perindustrian;

10 Bunyi Pasal 28 D Ayat (1) UUD 1945, sbb : "Setiap orang berhak atas pengakuan, jaminan, perlindungan, dan kepastian hukum yang adil serta perlakuan yang sama di hadapan hukum".

11 Bunyi Pasal 28I Ayat (2), berbunyi sbb: "Setiap orang berhak bebas dari perlakuan yang bersifat diskriminatif atas dasar apa pun dan berhak mendapatkan perlindungan terhadap perlakuan yang bersifat diskriminatif itu".

12 Sri Bakti Yunari dan Siti Nurbaiti, Laporan Hasil Penelitian, Inventarisasi Pengaturan Corporate Sosial Responsibility (CSR) Sebagai Legal Obligation Bagi Korporasi di Indonedia, Penelitian Desentralisasi - Hibah Bersaing, Kementerian Pendidikan Nasional, Jakarta, Tahun 2012, hal. 52-53. 
b. Undang-undang No. 7 Tahun 1992 tentang Perbankan juncto UU No. 10 Tahun 1998 tentang Perubahan terhadap UU No. 7 Tahun 1992 tentang Perbankan;

c. Undang-undang No. 41 Tahun 1999 tentang Kehutanan;

d. Undang-undang No. 5 Tahun 1999 tentang Larangan Praktek Monopoli dan Persaingan Usaha Tidak Sehat;

e. Undang-undang No. 8 Tahun 1999 tentang Perlindungan Konsumen;

f. Undang-undang No. 39 Tahun 1999 tentang Hak Asasi Manusia;

g. Undang-undang No. 22 Tahun 2001 tentang Minyak dan Gas Bumi;

h. Undang-undang No. 13 Tahun 2003 tentang Ketenagakerjaan;

i. Undang-undang No. 19 Tahun 2003 tentang Badan Usaha Milik Negara;

j. $\quad$ Undang-undang No. 27 Tahun 2003 tentang Panas Bumi;

k. Undang-undang No. 7 Tahun 2004 tentang Sumber Daya Air;

1. Undang-undang No. 25 Tahun 2007 tentang Penanaman Modal;

m. Undang-undang No. 4 Tahun 2009 tentang Pertambangan;

n. Undang-undang No. 30 Tahun 2009 tentang Ketenagalistrikan;

o. Undang-undang No. 32 Tahun 2009 tentang Perlindungan dan Pengelolaan Lingkungan Hidup;

p. Undang-undang No. 11 Tahun 2009 tentang Kesejahteraan Sosial;

q. Undang-undang No. 13 Tahun 2011 tentang Penanganan Fakir Miskin.

Dimana dari 17 (tujuh belas) UU Sektoral tersebut, ternyata hanya 12 UU Sektoral yang mengatur tentang sanksi, karena terdapat 5 (lima) UU Sektoral yang tidak mengatur tentang sanksi bagi perusahaan yang tidak menjalankan TJSLP, yaitu: ${ }^{13}$

a. UU No. 8 Tahun 1999 tentang Perlindungan Konsumen;

b. UU No. 39 Tahun 1999 tentang Hak Asasi Manusia;

c. UU No. 13 Tahun 2003 tentang Ketenagakerjaan;

d. UU N0. 19 Tahun 2003 tentang Badan Usaha Milik Negara; dan

e. UU No. 11 Tahun 2009 tentang Kesejahteraan Sosial.

Adapun bentuk-bentuk sanksi yang diatur didalam UU Sektoral bagi perusahaan yang tidak melaksanakan TJSLP, sbb $:^{14}$

a. Sanksi Administrasi berupa pencabutan ijin dan ganti rugi;

b. Sanksi Pidana pokok berupa penjara dan denda;

c. Sanksi Pidana Tambahan berupa tindakan tata tertib, antara lain :

1) Perampasan keuntungan yang diperoleh dari tindak pidana; dan atau

2) Penutupan seluruhnya atau sebagian perusahaan; dan/atau

3) Perbaikan akibat tindak pidana; dan/atau

13 Sri Bakti Yunari dan Siti Nurbaiti, "Regulasi Corporate Sosial Responsibility Pasca Berlakunya Peraturan Pemerintah No. 47/2012 tentang Tanggung Jawab Sosial dan Lingkungan Perseroan Terbatas”, Jurnal Hukum Bisnis, Volume 31, Nomor 5 Tahun 2012, Jakarta, hal. 578.

14 Sri Bakti Yunari dan Siti Nurbaiti, Op.Cit. hal. 52. 
4) Mewajibkan mengerjakan apa yang dilalaikan tanpa hak; dan/atau

5) Meniadakan apa yang dilalaikan tanpa hak; dan/atau

6) Menempatkan perusahaan di bawah pengampuan paling lama 3 (tiga) tahun.

Berdasarkan asas hukum Lex Specialis Derogat Lex Generalis ${ }^{15}$, maka sanksi-sanksi yang disebutkan diatas dapat diterapkan bagi perseroan yang berbentuk Perseroan Terbatas (PT) yang tidak melaksanakan TJSLP, yang justru menjadi masalah adalah terhadap UU Sektoral yang tidak mengatur tentang sanksi, maka sanksi yang diterapkan menjadi tidak jelas, sehingga hal tersebut dapat menimbulkan ketidakpastian hukum. Jadi, pengaturan penerapan sanksi TJSLP di Indonesia, masih mempunyai beberapa kelemahan bahkan regulasi yang dipandang sebagai sebuah keharusan / kewajiban hukum (legal obligation) tersebut berpotensi menimbulkan ketidakpastian hukum.

\section{Pengaturan Corporate Social Responsibility (CSR) di Taiwan}

Istilah CSR yang dipergunakan di negara Taiwan ada yang menggunakan istilah Corporate Social Responsibility (CSR) dan ada pula yang mengidentikkan dengan istilah "corporate management". Akan tetapi istilah yang lebih popular dipergunakan dalam bisnis di Taiwan adalah CSR. Adapun defenisi CSR menurut adalah:

"CSR is where a corporation takes into consideration the effects that its various business behaviours may have on society, then incorporates such considerations into its strategy and everyday actions so as to promote economic, social and environmental progress while at the same time accomplishing the enterprise's goal of sustainable development." 16

Dimana defenisi tersebut didasarkan pada Teori Five Forces Competitive Stategy, yang dikemukakan oleh Michael Porter, yang menyatakan bahwa: "Successful corporations need a healthy society ... [and] a successful society needs healthy companies. Porter juga mengarisbawahi hal penting dari CSR adalah : "Stressing that when social responsibility is linked to management strategy, it becomes a future source of competitive strength for a company”. Hal tersebut didukung oleh survey yang dilakukan oleh Pricewaterhouse Coopers' Tahun 2007 dalam catatan Global CEO Survey, yang menyatakan : "in the past, enterprises emphasized company profit; now they emphasize stakeholder profit; in the future they will emphasize societal profit. This shows that including CSR in corporate business strategies has become an important and pressing issue. Essentially, CSR starts with a corporation broadly understanding the demands of its various stakeholders, while also understanding the opportunities and risks it faces in meeting those demands, and then maintaining a consistent approach as its responds to them. In practice, corporations need to determine what is

\footnotetext{
15 Lex Specialis Derogat Lex Generalis adalah suatu asas yang dapat diartikan bahwa peraturan perundang-undangan yang bersifat khusus (special) mengesampingkan berlakukanya peraturan perundang-undangan yang bersifat umum (general), apabila keduanya memuat ketentuan yang saling bertentangan atau saling berbeda.

16 Wen Horng Kao, Corporate Social Responsibility in Taiwan, yang diakses pada tanggal 20 Agustus 2015, melalui Corporate\%20Social\%20Responsibility\%20in \%20Taiwan.html
} 
included in their conception of "society" (be it the environment, people, markets, or a more broadly defined community), and then progressively enhance their impact on society sodefined. Environmental and social impact is fairly clear with some industries, such as the oil industry and the automobile industry, so that enterprises can very easily identify them and clearly establish strategies and implementation guidelines. In something like the communications industry, on the other hand, it is not so easy find one's way. As for making CSR a reality, the most important thing is to incorporate, as part of one's operational strategy, a framework of CSR-related activity comprising four major areas: corporate governance, corporate commitments, social involvement and environmental protection. In so doing, the public interest is made an important touchstone for corporate policy. This is the sine qua non of a model CSR enterprise. ${ }^{17}$

Berdasarkan defenisi tersebut, dapat disimpulkan bahwa CSR adalah promosi perusahaan dibidang ekonomi, sosial dan lingkungan kepada masyarakat sebagai perilaku bisnis suatu perusahaan untuk pertimbangan strategi bisnis jangka pendek sehingga mencapai tujuan perusahaan yang berorientasi pada pembangunan berkelanjutan. Dalam hal pengaturan, pada awalnya berlakunya CSR, maka pengaturan CSR masih bersifat voluntary dan belum menjadi kewajiban hukum karena masih mengikuti konsep CSR yang berlaku didunia barat umumnya, dimana bidang utama CSR di Taiwan, sebagaimana tertuang dalam "The four main areas of CSR-related activity may be described as follows: ${ }^{18}$

a. Corporate governance: The essentials of good governance are concern for the interests of shareholders, an emphasis on board independence, and corporate transparency.

b. Corporate commitments: The scope of a corporation's commitments is relatively broad, comprising promises to customers, employee development and care, and investments in innovation and $R \& D$.

c. Social involvement: This relates to long-term and continuous investment of an enterprise's tangible and intangible resources on behalf of society.

d. Environmental protection: Investment in protecting the environment and conserving resources so as to "do no harm".

Selain itu terdapat 6 tahapan yang harus dilakukan oleh perusahaan agar menjadi " $a$ good corporate citizen" di Taiwan, yaitu $:{ }^{19}$

Step 1. Determine the enterprise's own definition of "corporate social responsibility".

Step 2. Assign responsibility for the enterprise's CSR policies.

Step 3. Establish concrete and visible examples of best practices within the enterprise and get active involvement from top management.

Step 4. Adopt pragmatic action; prepare workable budgets and plans..

Step 5. Develop and maintain passion with an attitude of continuous improvement.

Step 6. Accumulate "credit" and "results"; let all stakeholders understand the efforts being made. 
Demikian pula, jika kita mengkaji ketentuan yang mengatur tentang CSR di Taiwan, sebagaimana diatur dalam Company Act 1929 Taiwan, yang dikeluarkan pada tanggal 26 Desember 1929 dan mulai efektif diberlakukan tanggal 1 Juli 1931, yang kemudian telah diamandemen sebanyak 25 kali. $^{20}$ Dimana secara garis besar, materi Company Act 1929 Taiwan dan amandemen yang terdiri dari 9 BAB, 449 Pasal tersebut memuat hal-hal, sbb: ${ }^{21}$

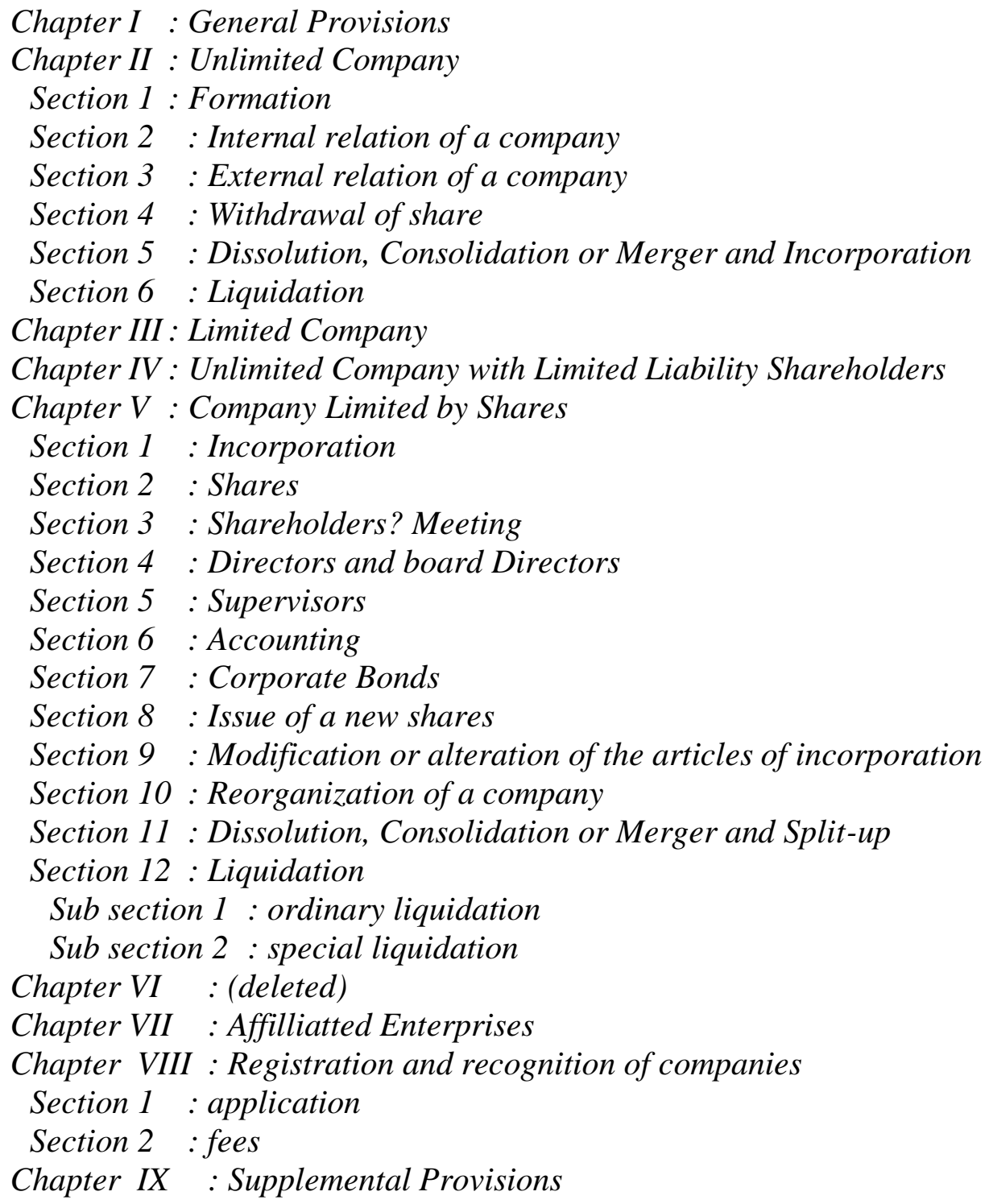

Berdasarkan content yang dijelaskan didalam Company Act 1929 Taiwan dan amandemennya tersebut diatas, dapat di analisis bahwa negara Taiwan tidak mengatur kewajiban CSR didalam Company Act 1929 Taiwan berikut amandemennya. Akan tetapi ketentuan yang mengatur tentang CSR justru diatur didalam The Taiwan Stock Exchange Corporation ("TWSE") and GreTai Securities Market ("GTSM"), sebagaimana tertuang dalam Corporate Social Responsibility Best Practice Principles for TWSE/GTSM Listed Companies yang juga mengacu pada G4-GRI (Global Reporting Inisiative), yang

${ }^{20}$ http://www.ly.gov.tw/en/innerIndex.action, diakses pada tanggal 10 September 2015, di Jakarta.

21 Ibid. 
diberlakukan sejak tanggal 6 Februari 2010 dan di amandemen pada tanggal 7 November 2015, dengan muatan materi secara garis besar terdiri dari :

Chapter 1 : General Principles (article 1-5)

Chapter 2 : Exercising Corporate Governance (article 6-10)

Chapter 3 : Fostering a sustainable Envirinment (article 11-17)

Chapter 4 : Preserving Public Welfare (article 18-27)

Chapter 5 : Enhancing Disclousure of CSR Information (28-29)

Chapter 6 : Supplementary Provision (30)

Berdasarkan materi muatan tersebut diatas, maka CSR hanya diterapkan pada perusahaan yang terdaftar dalam TWSE/GTSM, maka secara garis besar materinya membahas tentang pemberlakuan Prinsip CSR bagi perusahaan yang terdaftar, dimana didalam prinsip umum tersebut ditetapkan untuk membantu perusahaan yang terdaftar di Taiwan Bursa Efek Corporation ("TWSE") dan GreTai Securities Market ("GTSM") dan untuk memenuhi inisiatif tanggung jawab sosial perusahaan mereka serta mempromosikan kemajuan ekonomi, lingkungan, dan sosial untuk tujuan pembangunan berkelanjutan. TWSE dan GTSM ini mengadopsi Prinsip yang harus diikuti oleh perusahaan-perusahaan yang terdaftar TWSE / GTSM, dan disarankan untuk menyebarluaskan prinsip-prinsip tanggung jawab sosial perusahaan mereka sendiri sesuai dengan Prinsip-prinsip untuk mengelola risiko ekonomi, lingkungan dan sosial mereka dan dampaknya. Prinsip ini juga berlaku bagi seluruh operasi masing-masing perusahaan tersebut dan kelompok usahanya. Dimana Prinsip ini mendorong TWSE / GTSM untuk secara aktif memenuhi tanggung jawab sosial perusahaan mereka dalam perjalanan operasi bisnis sehingga dapat mengikuti perkembangan tren internasional dan untuk berkontribusi pada pembangunan ekonomi negara, untuk meningkatkan kualitas hidup karyawan, dan masyarakat, sebagai wujud warga korporasi yang bertanggung jawab, dan untuk meningkatkan keunggulan kompetitif yang dibangun di atas tanggung jawab sosial perusahaan. Dalam memenuhi inisiatif tanggung jawab sosial perusahaan, TWSE / GTSM dalam pedoman manajemen perusahaan dan operasi bisnis, memberikan pertimbangan hakhak dan kepentingan para pemangku kepentingan dan mengejar operasi serta keuntungan yang berkelanjutan, juga memberikan pertimbangan karena lingkungan, masyarakat dan tata kelola perusahaan. Untuk menerapkan inisiatif tanggung jawab sosial perusahaan TWSE/GTSM disarankan untuk mengikuti prinsip-prinsip di bawah ini:

a. Latihan tata kelola perusahaan.

b. Poster lingkungan yang berkelanjutan.

c. Pertahankan kesejahteraan masyarakat.

d. Meningkatkan pengungkapan informasi tanggung jawab sosial perusahaan.

Lebih lanjut TWSE / GTSM perusahaan yang terdaftar harus mempertimbangkan hubungan antara perkembangan prinsip-prinsip tanggung jawab sosial perusahaan domestik dan internasional dan operasi inti bisnis perusahaan, dan efek dari operasi perusahaan individu dan kelompok usaha masing-masing secara keseluruhan pada stakeholder, dalam membangun kebijakan, sistem atau pedoman manajemen yang relevan, dan rencana promosi konkret untuk program tanggung jawab sosial perusahaan, yang harus disetujui oleh dewan direksi dan 
kemudian dilaporkan ke rapat pemegang saham. Ketika pemegang saham mengusulkan gerakan yang melibatkan tanggung jawab sosial perusahaan, dewan direktur perusahaan disarankan untuk mengawasi dan mempertimbangkan termasuk dalam agenda rapat umum pemegang saham.

Selain itu bagi Perusahaan yang terdaftar TWSE / GTSM disarankan untuk mengikuti Corporate Governance Best Practice Prinsip untuk perusahaan TWSE / GTSM Terdaftar, Prinsip Etika Praktek Manajemen Perusahaan Yang Baik untuk perusahaan yang terdaftar dalam TWSE/ GTSM dan Kode Etik Emten untuk TWSE/ GTSM dalam membangun kerangka kerja tata kelola perusahaan yang efektif dan standar etika yang relevan sehingga dapat meningkatkan tata kelola perusahaan. Para direktur dari perusahaan yang terdaftar dalam TWSE/ GTSM juga harus melaksanakan pemeriksaan karena administrator yang baik untuk mendesak perusahaan untuk melakukan inisiatif tanggung jawab sosial perusahaan, mengawasi hasil dari pelaksanaannya dari waktu ke waktu dan terus melakukan penyesuaian sehingga untuk memastikan pelaksanaan menyeluruh dari kebijakan tanggung jawab sosial perusahaan. Dewan direksi dari perusahaan yang terdaftar dalam TWSE/ GTSM disarankan untuk memasukkan hal-hal sebagai berikut dalam kinerja perusahaan dari inisiatif tanggung jawab sosial perusahaan, yaitu :

a. Mengidentifikasi visi dan misi tanggung jawab sosial perusahaan, dan menyatakan kebijakan perusahaan tanggung jawab sosial, sistem atau pedoman manajemen yang relevan;

b. Membuat prinsip-prinsip tanggung jawab sosial perusahaan sesuai operasi dan pengembangan perusahaan, dan meratifikasi rencana promosi konkret untuk inisiatif tanggung jawab sosial perusahaan; dan

c. Meningkatkan ketepatan waktu dan ketepatan pengungkapan informasi tanggung jawab sosial perusahaan.

Dewan direksi harus menunjuk suatu posisi ditingkat eksekutif yang menangani tanggung jawab untuk masalah ekonomi, lingkungan, dan sosial yang dihasilkan dari operasi bisnis dari perusahaan yang terdaftar dalam TWSE/ GTSM, dan melaporkan status penanganan kepada dewan direksi. Prosedur penanganan dan orang yang bertanggung jawab untuk setiap isu yang relevan harus konkret dan jelas. TWSE/ GTSM disarankan untuk secara teratur mengatur pendidikan dan pelatihan tentang pelaksanaan inisiatif tanggung jawab sosial perusahaan. Untuk tujuan mengelola inisiatif tanggung jawab sosial perusahaan, perusahaan yang terdaftar TWSE/ GTSM disarankan pula untuk membentuk satuan khusus (atau bersamaan) yang didedikasikan untuk bertanggung jawab mengusulkan dan menegakkan kebijakan tanggung jawab sosial perusahaan, sistem, atau pedoman manajemen yang relevan, dan rencana promosi dan untuk melaporkan hal yang sama kepada dewan direksi secara periodik. Selain itu Perusahaan yang terdaftar TWSE/ GTSM disarankan juga untuk mengadopsi kebijakan remunerasi yang wajar, untuk memastikan bahwa pengaturan remunerasi mendukung tujuan strategis organisasi, dan menyelaraskan dengan kepentingan stakeholders. Hal ini disarankan sebagai sistem evaluasi kinerja karyawan dikombinasikan dengan kebijakan tanggung jawab sosial perusahaan, untuk membentuk insentif dan disiplin sistem yang jelas dan efektif. 
Selanjutnya Perusahaan yang terdaftar TWSE/ GTSM wajib menghormati hak-hak dan kepentingan para pemangku kepentingan, mengidentifikasi stakeholder perusahaan, dan membangun bagian yang ditunjuk untuk pemangku kepentingan di situs perusahaan; memahami harapan yang masuk akal dan tuntutan stakeholder melalui komunikasi yang tepat dengan mereka, dan memadai menanggapi isu-isu tanggung jawab sosial perusahaan penting yang mereka khawatir.

Terkait pembinaan lingkungan Berkelanjutan, perusahaan yang terdaftar TWSE/ GTSM harus mengikuti hukum lingkungan yang relevan, peraturan dan standar internasional untuk benar melindungi lingkungan dan wajib berupaya untuk meningkatkan lingkungan yang berkelanjutan ketika terlibat dalam operasi bisnis dan manajemen internal. Disarankan untuk berusaha memanfaatkan semua sumber daya yang lebih efisien dan menggunakan bahan terbarukan yang memiliki dampak yang rendah pada lingkungan untuk meningkatkan keberlanjutan sumber daya alam. Untuk membangun sistem manajemen lingkungan yang tepat berdasarkan karakteristik industri mereka. Adapun Sistem tersebut termasuk tugas-tugas berikut:

a. Mengumpulkan cukup dan up-to-date informasi untuk mengevaluasi dampak dari operasi bisnis perusahaan pada lingkungan alam.

b. Menetapkan tujuan yang terukur untuk kelestarian lingkungan, dan memeriksa apakah pengembangan tujuan tersebut harus dipertahankan dan apakah masih relevan secara teratur.

c. Mengadopsi langkah-langkah penegakan seperti rencana beton atau rencana aksi, dan memeriksa hasil operasi mereka secara teratur.

Selanjutnya dibentuk unit khusus atau menetapkan personil khusus untuk penyusunan, mempromosikan, dan memelihara sistem manajemen lingkungan yang relevan dan rencana aksi nyata, dan harus terus kursus pendidikan lingkungan bagi petugas manajerial dan karyawan lain pada periodik dasar. Serta memperhitungkan efek operasi bisnis pada efisiensi ekologi, mempromosikan dan mendukung konsep konsumsi berkelanjutan, dan melakukan penelitian dan pengembangan, pengadaan, produksi, operasi, dan layanan sesuai dengan prinsip untuk mengurangi dampak terhadap lingkungan alam dan manusia dari operasi bisnis mereka, sbb :

a. Mengurangi sumber daya dan konsumsi energi dari produk dan layanan mereka.

b. Mengurangi emisi polutan, racun dan limbah, dan membuang sampah dengan benar.

c. Meningkatkan daur ulang dan usabilitas bahan baku atau produk.

d. Maksimalkan keberlanjutan sumber daya terbarukan.

e. Meningkatkan daya tahan produk.

f. Meningkatkan efisiensi produk dan layanan.

Guna meningkatkan efisiensi penggunaan air, perusahaan harus benar dan berkelanjutan menggunakan sumber daya air dan menetapkan langkah-langkah manajemen yang relevan. Diharapkan perusahaan akan membangun dan meningkatkan fasilitas pengolahan perlindungan lingkungan untuk menghindari polusi air, udara dan tanah, dan menggunakan 
upaya terbaik mereka untuk mengurangi dampak buruk pada kesehatan manusia dan lingkungan dengan mengadopsi terbaik praktis langkah-langkah pencegahan dan pengendalian pencemaran. Serta mengadopsi standar atau pedoman umum yang digunakan di Taiwan dan luar negeri untuk menegakkan persediaan gas rumah kaca perusahaan dan membuat pengungkapan daripadanya, ruang lingkup yang akan meliputi:

a. Emisi gas rumah kaca langsung: emisi dari operasi yang dimiliki atau dikendalikan oleh perusahaan.

b. Emisi gas rumah kaca tidak langsung: emisi yang dihasilkan dari generasi eksternal dibeli atau diperoleh listrik, pemanas, atau uap.

Lebih lanjut Perusahaan harus memantau dampak perubahan iklim terhadap operasi mereka dan harus menetapkan strategi perusahaan untuk konservasi energi dan karbon dan gas rumah kaca pengurangan berdasarkan operasi mereka dan hasil dari inventarisasi gas rumah kaca. Strategi tersebut harus mencakup memperoleh kredit karbon untuk mempromosikan dan meminimalkan dampak dari operasi bisnis mereka tentang perubahan iklim.

Prinsip lain yang harus diterapkan bagi perusahaan TWSE / GTSM harus mematuhi hukum dan peraturan yang relevan, serta International Bill of Human Rights, sehubungan dengan hak-hak seperti kesetaraan gender, hak untuk bekerja, dan larangan diskriminasi. Untuk memenuhi tanggung jawabnya melindungi hak asasi manusia, harus mengadopsi kebijakan manajemen yang relevan dan proses, termasuk:

a. Menyajikan kebijakan perusahaan atau pernyataan tentang hak asasi manusia.

b. Mengevaluasi dampak dari operasi bisnis perusahaan dan manajemen internal pada hak asasi manusia, dan mengadopsi sesuai proses penyerahan.

c. Meninjau secara teratur efektivitas kebijakan perusahaan atau pernyataan tentang hak asasi manusia.

d. Dalam hal terjadi pelanggaran hak asasi manusia, perusahaan harus mengungkapkan proses untuk menangani masalah ini sehubungan dengan pemangku kepentingan yang terlibat.

Langkah-langkah yang ditempuh harus sesuai dengan hak asasi manusia yang diakui secara internasional dibidang ketenagakerjaan, termasuk kebebasan berserikat, hak perundingan bersama, merawat kelompok rentan, melarang penggunaan pekerja anak, menghilangkan segala bentuk kerja paksa, menghilangkan perekrutan dan diskriminasi kerja, dan harus memastikan bahwa kebijakan sumber daya manusia mereka tidak mengandung perawatan diferensial berdasarkan jenis kelamin, ras, status sosial ekonomi, usia, atau status perkawinan dan keluarga, sehingga mencapai kesetaraan dan keadilan dalam pekerjaan, mempekerjakan kondisi, remunerasi, tunjangan, pelatihan, evaluasi, dan promosi peluang. Adanya mekanisme pengaduan yang efektif dan tepat sehubungan dengan hal-hal yang berdampak negatif pada hak dan kepentingan tenaga kerja, untuk memastikan kesetaraan dan transparansi dari proses pengaduan. Saluran melalui mana keluhan yang dapat timbul harus 
jelas, nyaman, dan tidak terhalang. Sebuah perusahaan harus menanggapi keluhan setiap karyawan dengan cara yang tepat.

Demikian pula dengan kewajiban memberikan informasi bagi karyawan mereka sehingga karyawan memiliki pengetahuan tentang hukum perburuhan dan hak-hak mereka menikmati di negara-negara di mana perusahaan memiliki operasi bisnis. Termasuk menyediakan lingkungan kerja yang aman dan sehat bagi karyawan mereka, termasuk kesehatan dan pertolongan pertama fasilitas yang diperlukan dan akan berusaha untuk mengekang bahaya terhadap keselamatan dan kesehatan karyawan dan untuk mencegah kecelakaan kerja. Serta mengatur pelatihan keselamatan dan kesehatan bagi karyawan mereka secara teratur, untuk menciptakan lingkungan yang kondusif untuk pengembangan karir karyawan mereka dan membangun program pelatihan yang efektif untuk mendorong keterampilan karir. Dimana perusahaan harus tepat mencerminkan kinerja bisnis perusahaan atau prestasi dalam kebijakan remunerasi karyawan, untuk memastikan perekrutan, retensi, dan motivasi sumber daya manusia, dan mencapai tujuan operasi berkelanjutan. Serta membangun platform untuk memfasilitasi komunikasi dua arah yang teratur antara manajemen dan karyawan untuk karyawan untuk mendapatkan informasi yang relevan dan mengungkapkan pendapat mereka tentang operasi perusahaan, manajemen dan keputusan.

TWSE/GTSM juga harus menghormati hak-hak perwakilan karyawan untuk tawarmenawar untuk kondisi kerja, dan harus menyediakan karyawan dengan informasi yang diperlukan dan peralatan perangkat keras, dalam rangka meningkatkan negosiasi dan kerja sama antar pengusaha, karyawan dan perwakilan karyawan. Wajib dengan cara yang wajar, memberitahu karyawan perubahan operasi yang mungkin memiliki dampak material. Bertanggung jawab untuk produk dan layanan mereka, dan mengambil etika pemasaran serius. Dalam proses penelitian dan pengembangan, pengadaan, produksi, operasi, dan jasa, perusahaan harus menjamin transparansi dan keamanan produk dan layanan mereka. Mereka lebih lanjut harus menetapkan dan mengungkapkan kebijakan hak-hak konsumen dan kepentingan, dan menegakkan mereka dalam perjalanan operasi bisnis, untuk mencegah produk atau jasa dari berdampak negatif hak, kepentingan, kesehatan, atau keselamatan konsumen. Serta menjamin kualitas produk dan layanan mereka dengan mengikuti hukum dan peraturan standar pemerintah dan relevan dari industri mereka.

TWSE/GTSM harus mengikuti hukum, peraturan dan pedoman internasional ketika pemasaran atau label produk dan layanan mereka dan tidak akan menipu, menyesatkan, melakukan penipuan atau terlibat dalam tindakan lain yang akan mengkhianati hak atau kepentingan konsumen kepercayaan atau kerusakan konsumen. Perlu adanya evaluasi dan mengelola semua jenis risiko yang dapat menyebabkan gangguan dalam operasi, sehingga mengurangi dampak pada konsumen dan masyarakat. Memberikan prosedur yang jelas dan efektif untuk menerima keluhan konsumen untuk secara adil dan tepat waktu menangani keluhan konsumen, harus mematuhi hukum dan mperaturan yang terkait dengan UndangUndang Perlindungan Informasi Pribadi untuk menghormati hak-hak konsumen privasi dan akan melindungi pribadi data yang diberikan oleh konsumen. Menilai dampak pengadaan mereka memiliki pada masyarakat serta lingkungan masyarakat bahwa mereka pengadaan 
dari, dan harus bekerja sama dengan pemasok mereka untuk bersama-sama melaksanakan inisiatif tanggung jawab sosial perusahaan. Sebelum terlibat dalam transaksi komersial, perusahaan yang terdaftar TWSE / GTSM disarankan untuk menilai apakah ada catatan dampak pemasok terhadap lingkungan dan masyarakat, dan menghindari melakukan transaksi dengan orang-orang terhadap kebijakan tanggung jawab sosial perusahaan. Ketika perusahaan yang terdaftar dalam TWSE/ GTSM masuk ke dalam kontrak dengan salah satu pemasok utama mereka, konten harus mencakup hal penetapan saling sesuai dengan kebijakan tanggung jawab sosial perusahaan, dan bahwa kontrak dapat dihentikan atau dibatalkan setiap saat jika pemasok telah melanggar kebijakan tersebut dan telah menyebabkan dampak negatif yang signifikan terhadap lingkungan dan masyarakat dari komunitas sumber pasokan. TWSE/ GTSM harus mengevaluasi dampak dari operasi bisnis mereka di masyarakat, dan memadai mempekerjakan personil dari lokasi operasi bisnis, untuk meningkatkan penerimaan masyarakat.

Perusahaan yang terdaftar TWSE / GTSM disarankan untuk, melalui kegiatan komersial, wakaf properti non tunai, layanan sukarela atau jasa profesional amal lainnya, berpartisipasi dalam acara yang diadakan oleh organisasi warga, badan amal dan lembaga pemerintah daerah yang berkaitan dengan pengembangan masyarakat dan pendidikan masyarakat untuk mempromosikan masyarakat pembangunan.

Sedangkan prinsip kewajiban keterbukaan informasi Tanggung Jawab Sosial Perusahaan, bagi perusahaan yang terdaftar dalam TWSE/ GTSM harus mengungkapkan informasi sesuai dengan hukum, peraturan dan Tata Kelola Perusahaan berdasarkan Best Practice Prinsip bagi perusahaan yang terdaftar dalam TWSE / GTSM dan harus sepenuhnya mengungkapkan informasi yang relevan dan dapat diandalkan terkait dengan inisiatif tanggung jawab sosial perusahaan mereka untuk meningkatkan transparansi informasi. Informasi yang relevan yang berkaitan dengan tanggung jawab sosial perusahaan harus mengungkapkan meliputi:

a. Kebijakan, sistem atau pedoman manajemen yang relevan, dan rencana promosi konkret untuk inisiatif tanggung jawab sosial perusahaan, seperti diselesaikan oleh dewan direksi.

b. Risiko dan dampak pada operasi perusahaan dan kondisi keuangan yang timbul dari berolahraga tata kelola perusahaan, membina lingkungan yang berkelanjutan dan melestarikan kesejahteraan masyarakat sosial.

c. Tujuan dan langkah-langkah untuk mewujudkan inisiatif tanggung jawab sosial perusahaan yang didirikan oleh perusahaan, dan kinerja dalam pelaksanaan.

d. pemangku kepentingan utama dan keprihatinan mereka.

e. Pengungkapan informasi pada manajemen dan kinerja pemasok utama sehubungan dengan isu-isu lingkungan dan sosial yang besar.

f. Informasi lain mengenai inisiatif tanggung jawab sosial perusahaan.

Perusahaan yang terdaftar dalam TWSE / GTSM harus mengadopsi standar internasional secara luas dan diakui atau pedoman ketika memproduksi laporan tanggung jawab sosial perusahaan, untuk mengungkapkan status pelaksanaannya kebijakan tanggung jawab sosial perusahaan. Hal ini juga disarankan untuk mendapatkan jaminan pihak ketiga atau verifikasi 
untuk laporan untuk meningkatkan keandalan informasi dalam laporan. Laporan disarankan dengan menyertakan sbb :

a. Kebijakan, sistem, atau pedoman manajemen yang relevan dan rencana promosi konkret untuk mengimplementasikan inisiatif tanggung jawab sosial perusahaan.

b. pemangku kepentingan utama dan keprihatinan mereka.

c. Hasil dan review dari berolahraga tata kelola perusahaan, pembinaan lingkungan yang berkelanjutan, pelestarian kesejahteraan dan promosi pembangunan ekonomi masyarakat.

d. perbaikan masa depan dan tujuan.

Selanjutnya, perusahaan yang terdaftar dalam TWSE / GTSM harus setiap saat memantau perkembangan standar tanggung jawab sosial dalam dan luar negeri perusahaan dan perubahan lingkungan bisnis sehingga dapat memeriksa dan meningkatkan corporate kerangka tanggung jawab mereka didirikan sosial dan untuk mendapatkan hasil yang lebih baik dari pelaksanaan korporasi kebijakan tanggung jawab sosial. Jadi, bagi perusahaan yang terdaftar dalam Bursa Efek Taiwan, mereka harus menjalankan prinsip-prinsip CSR sebagaimana tertuang dalam G4 Global Reporting Initiative (G4-GRI) sebagaimana tersebut diatas. Bahkan sejak tanggal 26 November 2014, yang kemudian diamandemen pada tanggal 27 Maret 2015, negara Taiwan telah mengeluarkan suatu kewajiban hukum berupa Taiwan Stock Exchange Corporate Social Responsibility Governing The Preparation and Filing of Corporate Social Responsibility reports by TWSE list companies. ${ }^{22}$

Berdasarkan penjelasan ketentuan tersebut diatas, maka Bursa Efek Taiwan (TWSE) akan menjadi pasar pertama di Asia-Pasifik yang mewajibkan melaksanakan pelaporan CSR (mandatory), dengan tetap berpegang pada prinsip-prinsip G4 Global Reporting Initiative (GRI). Kewajiban pelaksanaan pelaporan tanggung jawab sosial perusahaan tersebut akan dilakukan setiap tahunnya mulai Tahun 2015. Adapun kewajiban pelaporan terhadap perusahaan yang terdaftar di Bursa Efek Taiwan, termasuk perusahaan dari pengolahan makanan, sektor keuangan dan kimia, serta perusahaan yang memiliki lebih dari $50 \%$ dari total pendapatan mereka berasal dari bisnis makanan dan minuman. Demikian pula berlaku bagi perusahaan besar dengan modal disetor tidak kurang dari NT \$10.000.000. Bagi perusahaan pengolahan makanan harus mendapatkan verifikasi eksternal pada pelaporan CSR mereka. Pelaporan G4 CSR harus selesai pada akhir Juni setiap tahun. Namun, bagi perusahaan terdaftar tidak menyiapkan laporan tanggung jawab sosial perusahaan pada tahun terbaru atau tidak menyiapkan laporan dengan mengacu pada Pedoman GRI, atau hanya membuat laporan CSR dalam bentuk pendapat dalam surat CPA, pengajuan dapat dilakukan pada tanggal 31 Desember. Langkah ini mengikuti langkah-langkah baru dan aturan yang ditetapkan oleh Komisi Pengawasan Keuangan Taiwan dan dikodifikasi oleh TWSE. Untuk kepentingan sosialisasi TWSE akan terus mengadakan konferensi-konferensi tentang tata kelola perusahaan, seminar-seminar dan pelatihan bagi masyarakat bisnis, dan sesi berbagi pengalaman. TWSE mengharapkan langkah ini akan membantu pasar modal Taiwan untuk

22 http://twse-regulation.twse.com.tw/ENG/EN/law/DAT 0201.aspx?FLCODE=FL052368, yang diakses pada tanggal 11 September 2015 di Jakarta. 
menarik lebih banyak investor untuk mencari peluang investasi yang berkelanjutan. Bahkan sebelumnya dengan diluncurkan oleh GRI G4-10 Sektor Keterbukaan, hal ini dimaksudkan untuk membantu industri tertentu menyiapkan laporan keberlanjutan, yaitu sector-sektor sebagai berikut: operator bandara, konstruksi dan real estate, utilitas listrik, event organizer, jasa keuangan, pengolahan makanan, pertambangan dan logam, media, LSM, dan minyak dan gas. Sayangnya pengaturan kewajiban pelaporan CSR secara mandatory oleh perusahaan yang terdaftar dalam TWSE tidak mengatur mengenai sanksi.

\section{Perbandingan Pengaturan TJSLP Di Indonesia Dan CSR Di Taiwan}

Berdasarkan analisis mengenai perbandingan pengaturan TJSLP di Indonesia dan CSR di Taiwan, maka terdapat persamaan didalam pengaturan dan konsep yang diterapkan untuk TJSLP di Indonesia dengan pengaturan CSR di Taiwan yang mengarah kepada "Mandatory", meskipun di Taiwan ruanglingkupnya berbeda dengan di Indonesia. Dimana jika di Indonesia diatur didalam Pasal 74 UUPT juncto PP No 47 Tahun 2012. Sedangkan di Taiwan diatur oleh The Taiwan Stock Exchange Corporation ("TWSE") and GreTai Securities Market ("GTSM"), sebagaimana tertuang dalam Corporate Social Responsibility Best Practice Principles for TWSE/GTSM Listed Companies yang juga mengacu pada G4-GRI (Global Reporting Inisiative). Selanjutnya, sejak tanggal 26 November 2014, yang kemudian diamandemen pada tanggal 27 Maret 2015, negara Taiwan telah mengeluarkan suatu kewajiban hukum berupa Taiwan Stock Exchange Corporate Social Responsibility Governing The Preparation and Filing of Corporate Social Responsibility reports by TWSE list companies. $^{23}$ Oleh karena itu dapat dikatakan bahwa terdapat persamaan pengaturan dan konsep yang diterapkan untuk pengaturan TJSLP di Indonesia dengan pengaturan CSR di Taiwan. Adapun persamaan pengaturannya adalah sama-sama mengarah kepada "Mandatory", dimana di Indonesia kewajiban hukum TJSL untuk perusahaan yang berbentuk PT yang kegiatan usahanya dibidang SDA dana tau terkait dengan sumber daya alam, sedangkan di Taiwan kewajiban CSR hanya diperuntukkan bagi perusahaan TWSE/ GTSM.

Akan tetapi berdasarkan hasil analisis, disamping terdapat persamaan pengaturan TJSLP di Indonesia dan CSR di Taiwan sebagai mandatory, maka terdapat beberapa perbedaan materi yang diatur didalam ketentuan yang bersifat mandatory tersebut baik di negara Indonesia maupun di negara Taiwan. Hal tersebut terkait perbedaan dalam penggunaan istilah, ruang lingkup berlakunya CSR, bentuk kegiatan, pelaksanaan CSR, besaran kewajiban CSR yang dibebankan kepada perusahaan, dan lembaga pengawas bagi pelaksanaan CSR, bahkan termasuk mengenai pemberlakuan sanksi bagi perusahaan yang tidak menjalankan kewajiban CSR, sebagaiman tertuang dalam tabel sbb:

\footnotetext{
23 http://twse-regulation.twse.com.tw/ENG/EN/law/DAT 0201.aspx?FLCODE=FL075209, yang diakses pada tanggal 12 September 2015, di Jakarta.
} 
Tabel 1.

\section{Perbedaan Materi Pengaturan TJSLP di Negara Indonesia dan Pengaturan CSR Di Negara Taiwan}

\begin{tabular}{|c|c|c|c|}
\hline No & $\begin{array}{c}\text { Materi } \\
\text { Pengaturan }\end{array}$ & Negara Indonesia & Negara Taiwan \\
\hline 1. & $\begin{array}{l}\text { Penggunaan } \\
\text { istilah }\end{array}$ & $\begin{array}{l}\text { Istilah yang digunakan di UUPT } \\
\text { adalah Tanggung Jawab Sosial } \\
\text { dan Lingkungan Perseroan } \\
\text { (TJSLP). Sedangkan istilah } \\
\text { yang digunakan di UUPM } \\
\text { adalah Tanggung Jawab Sosial } \\
\text { Perusahaan (TJSP). }\end{array}$ & $\begin{array}{l}\text { Istilah yang digunakan adalah Corporate Sosial } \\
\text { Responsibility atau corporate management }\end{array}$ \\
\hline 2. & $\begin{array}{l}\text { Ruang } \\
\text { lingkup } \\
\text { berlakunya }\end{array}$ & $\begin{array}{l}\text { Hanya diberlakukan bagi } \\
\text { perusahaan yang berbentuk } \\
\text { Perseroan Terbatas, yang } \\
\text { menjalankan yang menjalankan } \\
\text { kegiatan usahanya di bidang } \\
\text { dan/atau berkaitan dengan } \\
\text { sumber daya alam, yang } \\
\text { dilaksanakan baik di dalam } \\
\text { maupun di luar lingkungan } \\
\text { Perseroan. }\end{array}$ & $\begin{array}{l}\text { Ketentuan Taiwan CSR, diberlakukan bagi semua } \\
\text { perusahaan yang telah terdaftar di TWSE, daftar di } \\
\text { Bursa Efek Taiwan, termasuk perusahaan dari } \\
\text { pengolahan makanan, sektor keuangan dan kimia, } \\
\text { serta perusahaan yang memiliki lebih dari } 50 \% \text { dari } \\
\text { total pendapatan mereka berasal dari bisnis makanan } \\
\text { dan minuman. Demikian pula berlaku bagi } \\
\text { perusahaan besar dengan modal disetor tidak kurang } \\
\text { dari NT \$ } 10.000 .000 \text {. Bagi perusahaan pengolahan } \\
\text { makanan harus mendapatkan verifikasi eksternal } \\
\text { pada pelaporan CSR mereka. Pelaporan G4 CSR } \\
\text { harus selesai pada akhir Juni setiap tahun. Namun, } \\
\text { bagi perusahaan terdaftar tidak menyiapkan laporan } \\
\text { tanggung jawab sosial perusahaan pada tahun terbaru } \\
\text { atau tidak menyiapkan laporan dengan mengacu pada } \\
\text { Pedoman GRI, atau hanya membuat laporan CSR } \\
\text { dalam bentuk pendapat dalam surat CPA, pengajuan } \\
\text { dapat dilakukan pada tanggal 31 Desember, } \\
\text { termasuk. Industri-industri tertentu yaitu sektor- } \\
\text { sektor operator bandara, konstruksi dan real estate, } \\
\text { utilitas listrik, event organizer, jasa keuangan, } \\
\text { pengolahan makanan, pertambangan dan logam, } \\
\text { media, LSM, dan minyak dan gas. }\end{array}$ \\
\hline 3. & Tujuan & $\begin{array}{l}\begin{array}{l}\text { Meningkatkan taraf hidup dan } \\
\text { kesejahteraan } \\
\text { sekitar. }\end{array} \\
\text { masyarakat }\end{array}$ & $\begin{array}{l}\text { Tujuannya untuk pembangunan berkelanjutan } \\
\text { (sustainable development) }\end{array}$ \\
\hline 4. & $\begin{array}{l}\text { Bentuk } \\
\text { kegiatan }\end{array}$ & $\begin{array}{l}\text { Bentuk kegiatan TJSLP Tidak } \\
\text { diatur secara tegas dan specifik, } \\
\text { akan tetapi disesuaikan dengan } \\
\text { kegiatan usaha Perseroan. }\end{array}$ & $\begin{array}{l}\text { Bentuk kegiatan CSR, segala perbuatan yang } \\
\text { berdampak pada lingkungan, sosial, ekonomi dan } \\
\text { keuangan, berupa: pelatihan tata kelola perusahaan; } \\
\text { membuat Poster lingkungan yang berkelanjutan; } \\
\text { mempertahankan kesejahteraan masyarakat; serta } \\
\text { Meningkatkan keterbukaan informasi tanggung } \\
\text { jawab sosial perusahaan. }\end{array}$ \\
\hline 5. & Pelaksanaan & $\begin{array}{l}\text { dilaksanakan oleh Direksi } \\
\text { berdasarkan rencana kerja } \\
\text { tahunan Perseroan setelah } \\
\text { mendapat persetujuan Dewan } \\
\text { Komisaris atau RUPS sesuai } \\
\text { dengan anggaran dasar } \\
\text { Perseroan. Rencana kerja } \\
\text { tahunan Perseroan memuat } \\
\text { rencana kegiatan dan anggaran } \\
\text { yang dibutuhkan untuk } \\
\text { pelaksanaan TJSLP. Dimana }\end{array}$ & $\begin{array}{l}\text { Dilaksanakan oleh Direksi yang ditunjuk oleh Dewan } \\
\text { direksi untuk menangani CSR yang dihasilkan dari } \\
\text { operasi bisnis dari perusahaan yang terdaftar dalam } \\
\text { TWSE, dan melaporkan status penanganan kepada } \\
\text { dewan direksi. Prosedur penanganan dan orang yang } \\
\text { bertanggung jawab untuk setiap isu CSR yang } \\
\text { relevan harus konkret dan jelas. TWSE secara teratur } \\
\text { mengatur pendidikan dan pelatihan tentang } \\
\text { pelaksanaan inisiatif tanggung jawab sosial } \\
\text { perusahaan. Untuk tujuan mengelola inisiatif } \\
\text { tanggung jawab sosial perusahaan, perusahaan yang }\end{array}$ \\
\hline
\end{tabular}




\begin{tabular}{|c|c|c|c|}
\hline & & $\begin{array}{l}\text { Realisasi anggaran untuk } \\
\text { pelaksanaan TJSLP } \\
\text { diperhitungkan sebagai biaya } \\
\text { Perseroan. Serta dimuat dalam } \\
\text { laporan tahunan Perseroan dan } \\
\text { dipertanggungjawabkan kepada } \\
\text { RUPS. }\end{array}$ & $\begin{array}{l}\text { terdaftar TWSE disarankan pula untuk membentuk } \\
\text { satuan khusus (atau bersamaan) yang didedikasikan } \\
\text { untuk bertanggung jawab mengusulkan dan } \\
\text { melaksanakan kebijakan tanggung jawab sosial } \\
\text { perusahaan, sistem, atau pedoman manajemen yang } \\
\text { relevan, dan rencana promosi dan untuk melaporkan } \\
\text { hal yang sama kepada dewan direksi secara periodik. }\end{array}$ \\
\hline 6. & $\begin{array}{l}\text { besaran } \\
\text { kewajiban } \\
\text { CSR }\end{array}$ & $\begin{array}{l}\text { Harus memperhatikan kepatutan } \\
\text { dan kewajaran, artinya } \\
\text { disesuaikan dengan kemampuan } \\
\text { keuangan Perseroan, dan } \\
\text { potensi risiko yang harus } \\
\text { ditanggung oleh Perseroan, dan } \\
\text { diperhitungkan sebagai biaya } \\
\text { Perseroan. Jadi tidak diatur } \\
\text { berapa besaran pasti. }\end{array}$ & $\begin{array}{l}\text { Tidak ditentukan besaran CSR tetapi harus sesuai } \\
\text { dengan besarnya kerugian yang diakibatkan adanya } \\
\text { pelanggaran CSR. }\end{array}$ \\
\hline 6. & $\begin{array}{l}\text { lembaga } \\
\text { pengawas } \\
\text { Pelaksanaan }\end{array}$ & $\begin{array}{l}\text { Tidak ada lembaga pengawas } \\
\text { bagi pelaksanaan TJSLP }\end{array}$ & Komisi Pengawasan Keuangan Taiwan. \\
\hline 7. & $\begin{array}{l}\text { Sanksi bagi } \\
\text { perusahaan } \\
\text { yang tidak } \\
\text { menjalankan } \\
\text { kewajiban } \\
\text { CSR. }\end{array}$ & $\begin{array}{l}\text { Mengatur tentang sanksi tapi } \\
\text { tidak tegas, karena merujuk } \\
\text { kepada sanksi yang terdapat } \\
\text { pada } 12 \text { (dua belas) UU Sektoral } \\
\text { dari } 17 \text { (tujuh belas) UU } \\
\text { sektoral yang mengatur TJSLP. }\end{array}$ & Tidak Mengatur tentang sanksi. \\
\hline
\end{tabular}

\section{E. Kesimpulan}

Pada prinsipnya terdapat persamaan dan perbedaan didalam pengaturan TJSLP di Indonesia dengan CSR di Taiwan. Adapun persamaannya bahwa TJSLP di Indonesia maupun CSR di Taiwan merupakan kewajiban hukum yang harus dijalankan oleh perusahaan yang bersifat mandatory. Akan tetapi selain persamaan ternyata terdapat perbedaan dalam pengaturannya, khususnya terkait pengunaan istilah, ruang lingkup, tujuan, bentuk kegiatan, pelaksanaan, besaran biaya, lembaga pengawas dan sanksinya. Akan tetapi TJSLP di Indonesia dan CSR di Taiwan yang diwajibkan bagi perusahaan harus dipandang sebagai niat baik yang bertujuan untuk meningkatkan taraf hidup dan kesejahteraan masyarakat sekitar dan pembangunan yang berkelanjutan.

\section{Daftar Pustaka}

\section{Buku \& Jurnal}

Lexy J. Moleong, Metodologi Penelitian Kualitatif, Remadja Karya, Bandung, 1989.

Maria Farida Indrati S, Ilmu Perundang-undangan - Proses dan Teknik Pembentukannya, Kanisius, Yogykarta, 2008.

Soerjono Soekanto, Pengantar Penelitian Hukum, Penerbit UI Press, Jakarta, 1982. 
Sri Bakti Yunari dan Siti Nurbaiti, Laporan Hasil Penelitian, Inventarisasi Pengaturan Corporate Sosial Responsibility (CSR) Sebagai Legal Obligation Bagi Korporasi di Indonedia, Penelitian Desentralisasi - Hibah Bersaing, Kementerian Pendidikan Nasional, Jakarta, Tahun 2012.

, "Regulasi Corporate Sosial Responsibility Pasca Berlakunya Peraturan Pemerintah No. 47/2012 tentang Tanggung Jawab Sosial dan Lingkungan Perseroan Terbatas”, Jurnal Hukum Bisnis, Volume 31, Nomor 5 Tahun 2012, Jakarta.

Corporate Social Responsibility Best Practice Principles for TWSE/ GTSM Listed Companies.

Taiwan Stock Exchange Corporate Social Responsibility Governing The Preparation and Filing of Corporate Social Responsibility reports by TWSE list companies.

\section{Peraturan Perundang-Undangan dan Putusan Pengadilan}

Undang-Undang Dasar Negara Republlik Indonesia Tahun 1945

Undang-Undang Nomor 40 Tahun 2007 tentang Perseroan Terbatas

Peraturan Pemerintah Nomor 47 Tahun 2012 tentang Tanggung jawab Sosial dan Lingkungan Perseroan Terbatas.

Putusan Mahkamah Konstitusi Nomor 53/PUU-VI/2008 Perihal Pengujian Undang-Undang Nomor 40 Tahun 2007 tentang Perseroan terbatas.

\section{Internet}

Wen Horng Kao, Corporate Social Responsibility in Taiwan, Corporate\%20 Social\%20Responsibility\%20in\%20 Taiwan.html, diakses pada tanggal 20 Agustus 2015

http://www.ly.gov.tw/en/innerIndex.action, yang diakses pada tanggal 10 September 2015, di Jakarta.

http://twse-regulation.twse.com.tw/ENG/ EN/law/DAT0201.aspx?FLCODE=FL052368, yang diakses pada tanggal 11 September 2015 di Jakarta.

http://twse-regulation.twse.com.tw/ENG/ EN/law/DAT0201.aspx?FLCODE=FL075209, yang diakses pada tanggal 12 September 2015, di Jakarta. 